\title{
INTERACTIVE TEACHING IN WRITING SESSION OF ENGLISH DEPARTMENT STUDENTS
}

\author{
Wirhayati \\ Pamulang University \\ dosen00170@unpam.ac.id
}

\begin{abstract}
Interactive writing is a writing process used to teach students how to write a paragraph. The process involves the sharing of writing between the teacher and students. It can be in a group of students. The purpose of this research was to know the development of writing skill in the students of English Department through interactive method. All participants were the students of the English Department Faculty of Letters of Pamulang University. Interactive writing is an effective method as the teacher role is very important. A Theory used is Brown's theory (2000). The procedure is to teach students how to write well by allowing them to directly copy the demonstration of the teacher. Interactive writing helps students improve their writing skills as using the same example as the teacher and creates the right mindset for the students to copy the technique of writing a paragraph by the teacher correctly. By directly following the guide of the teacher, the students writing is better than they use their own writing. As an introduction to writing, interactive writing is a useful and successful technique for teachers to use in teaching the basics.
\end{abstract}

Key words: effective, interactive, procedure, writing

\section{INTRODUCTION}

Writing skills are an important part of communication. The study of writing teaches students how to convey information, messages, ideas, and events in the grammatically correct cluster of sentences. Good writing skills allow you to communicate your ideas with clarity and ease to many people than through face to face or telephone conversation. And of course, a well written of paragraph or essay with no spelling or grammatical mistakes is essential if you want to create a report or others. Poor writing skills give bad impression and many readers will have an immediate negative reaction. Since English is a foreign language in Indonesia writing a paragraph or essay is not easy for the students. Writing is a process that requires aspects of specific aspects that must be considered to produce good writing. As students of English Department they follow and learn how to write a good paragraph or essay in accordance with the standard of teaching English to improve the ability to write effectively in accordance with the targets to be achieved. In addition, writing is a skill which can be learned like any other. By practicing more, for example writing a conversation, taking notes, preparing a report and writing experiences for minutes can improve your writing skills.

Many people say that the art of writing is difficult because writing is felt to be slower and more difficult. On the other hand, writing skills are indispensable both in school life and in society. Students need writing skills to copy, record or complete their tasks. Students need the ability to write for the purpose of sending letters, filling out forms, or making notes. Expressive writing is expressing thoughts and or feelings into a form of writing, so that it can be understood Lexeme : Journal of Linguistics and Applied Linguistics, Vol 2(1), $2020 \mid$ 
by others. Expressive writing is also called composing or composition. In order to be able to write expressively students must have the ability to speak, read, spell, write clearly, and understand the various rules that apply to a type of writing. Harmer (2007) explains, as a teacher in teaching writing to students, we have to differentiate between writing for learning and writing for writing because they both have different goals. Writing for learning means students practice writing as they have learnt and instruct by a teacher to practice writing sentences using new words. While writing for writing leads student in writing to produce something such as, a letter, an email or report. In this case students should be good at writing and must develop their skills in creating a good composition.

Writing is an exciting and rewarding activity for students if they already know and understand the correct way of writing. So that writing activities becomes a normal part of classroom and habit. In this case, the role of teachers or lecturers is very important to support student activeness in writing. It should be understood to the students that they must understand correctly with what will be written. It is important that the understanding of what is to be written must be completely clear so that the information or message to be conveyed to reader is clear. Many aspects to note in writing are not only grammatical but also including capitalization, punctuation and content. Also students must aware to produce a good writing, it involves a process of writing, drafting reviewing, and editing.

Since English is a foreign language and many things that must be considered to produce good writing according to the applicable standards. One of solutions to produce a good writing is to train a student on continuous writing is one effective way to reduce mistakes and improve their writing skills. Many students have difficulty to write because of their lack of knowledge about writing and also lack of practice. When they get into trouble and there is no significant increase in writing, it makes them lazy to continue. To overcome the problems faced by the students in writing need to find a solution so that the constraints faced when writing can be overcome and they still want to continue writing and do not stop when faced with the problem. The difficulties students face when writing are an important issue and must be solved. Usually the errors that students often encounter are the use of inaccurate grammatical, unintelligible sentences and meaningless sentences. This error is often found in writing a paragraph or essay because of their lack of understanding and ignorance of it. It is necessary for a teacher or a lecturer to teach on how to write well according to the applicable English teaching standards. To achieve the purpose of teaching writing as expected, then it is necessary to find and apply an interesting and effective method so that students can follow and gain a lot of knowledge, pleasure and motivation to write more.

In mastering writing skills, students need to know a lot about writing knowledge and they have to learn how to write correctly. Therefore, there are kind of methods can be used by teachers or lecturers in improving the ability to master writing by students. Selection of appropriate and attractive methods will give good results on their written works. The chosen method is a strategy that can motivate them to write more and train them to write the right and good in accordance with the rules of grammar and the system applicable in teaching English. English is a foreign language studied by students ranging from school to university, so it is not easy for them to express their ideas, information or experiences in English. Therefore, it takes a lot of practice and time to write something that is in their mind.

To improve students writing skills, a teacher or a lecture have to find method and technique which is effective and interesting for students. One of effective method is interactive writing. It can be used as a method of teaching writing to students. As the students, they develop their literacy skills more and more, they become more able to work independently. This is often more effective at later stages as they are able to practice their skills at a faster pace. However as an introduction to writing, interactive writing is a useful technique for teachers to use, as it is successful in teaching the basics. It is important for students to have an active learning experience to develop their writing skills. Oxford (2011) examined, a teacher talks with the 
students to establish what they will write about is valuable. Then the text is constructed; this should be done as far as possible by the students. The activity can be done individually or in a group with the teacher giving help when it is needed. Interactive writing is all in all a very effective way for teachers or lectures to help students begin to learn to write. The method is most effective with smaller groups of students or individuals as they are able to have more time using the pen. A strong teacher-student relationship also helps to ensure the success of the technique, as the role of the teacher is very important in the system.

Interactive writing activities motivate students to write, since the students are asked to write immediately in response to the lecture request. Rivers (1987) said, a teacher can ask students to write a paragraph about topics given and provides them some words or ideas to put in their writing. Students learn naturally and use messages from what they hear. This technique is designed to make students active and comfortable when writing and also give them thinking time before they read their writing in the classroom. Often the teacher or lecture does this with the students to help them learn what the different words and letters sound like. Often the text is revisited later in the class to help the students remember what the words look and sound like. If the lesson is a success with the majority of the class, the teacher may choose to extend the learning to make it more difficult. The problem is found and then summarized into the following questions (1) how is the student's writing skills using interactive teaching?; (2) what activities are used in teaching students through interactive teaching?; (3) what is the result of student's writing skills using interactive teaching?

\section{LITERARY REVIEW}

The data were analyzed using some theories, Oshima (1998) says that writing is a process, not a product and any kinds of writing, whether it is a composition for an English class or lab report for a chemistry class, is never perfect, it is always possible to review and revise, and review and revise again. It means that learners need to do some steps to produce a good result of their writing. Next, Harmer (2011) explains, Students make mistakes in their writing, slips or errors are commonly mistakes cover all terms in wrongness. Then, According to Tarigan (2008) writing is the activity of expressing idea and mind into the form of graphic symbols to become a unified language unity, so that others can read the symbols of that language in form of essay. O'Malley and Pierce (1996), says the author uses a way of writing to convey or inform news, ideas or pointers to the reader with a form describing events and experiences, analyzing concepts, causal and developing related new ideas. And then, Johnson and Smith (1998), argue that teacher-centered learning and student-centered learning have their own benefits in educating students. Moreover, students are commonly write text by looking at their teacher's writing and they usually creates a composition by imitating. As Brown (2000:50) explains, "Imitation is consonant with behavioristic principles of language acquisition-principles relevant, at least, to the earliest stages". It is known that the process of students' writing is influence with their interaction and repetition as their learning in the class.

\section{METHOD}

Data and sources of this research were from the students of English literature Pamulang University and writing or essay made by the students themselves. As Sutopo (2002) explains, the data source is a very important part for researchers in analyzing the study because of the accuracy of selecting and determining the accuracy and wealth of data or information obtained. The approach used in this research was important for explaining the results of later inventions. And the method used in this research is descriptive qualitative. According to Cresswell (1994), qualitative research is qualitative data in the form of words, and is conducted in the reality of the object in its natural setting. Then, Flick (2007:57) states, "a major part of qualitative research is based on text and writing form field notes and transcripts to description and interpretation and finally to the presentation of the findings and of the research as a whole". Based on expert 
opinion above, it is clear that qualitative descriptive method is a research method that produces descriptive data described in the form of words, schemes, and images. Then in the data collection there were several steps taken to get the data clear and true, first was the interview given to the lecturer who taught the writing course. Furthermore, the observation was done to know the learning and teaching activities in the classroom. And last was the questionnaire given to the students to know the reciprocal of the results of the activities that have been done.

\section{FINDINGS AND DISCUSSION}

\section{Description of Interactive Teaching Writing Skill to Students}

In teaching and learning writing, it is important for students to have an active learning experience to develop their writing skills. In order to motivate students active in classroom, so interactive writing provides students in developing their activities in writing. The teacher first talked with the students to think what they would write about, the teacher guided students to write, then, the text was constructed. The writing should have been done as far as possible by the students with the teacher giving help when it was needed. The text was then read; often the teacher did this with the students to help them learn what the different words and letters sound like. After correcting, the text was revisited later. They could also discuss it with a group of friends made by a teacher to help the students remember what the words look and sound like. If the students could do it well, a teacher might continue to lesson for the next meeting in the class with different topic of writing. The teacher might choose the topic to extend the learning to make it more difficult.

Interactive writing is one of methods which is an effective way for teachers or lecturers to help students begin to learn to write. The method is most effective with smaller groups of students as they are able to have more time using the pen. A strong teacher-students relationship also helps to ensure the success of the technique, as the role of the teacher is very important in the system.

\section{Interactive Teaching writing with a Paragraph}

In this study, the data collected for compiling the report was obtained from observations, interviews, questionnaires, and document review. Learning writing for students of the 3rd semester had reached the advanced writing stage. The learning had led to the preparation of writing descriptions and narratives as a means of expression and communication that was not too simple. In class they were only required to write a paragraph in narrative or descriptive.

Writing lessons learned by students are already in simple paragraph writing with a structured technique. Writing activities had begun in the exercise of pouring ideas, feelings, and experiences through writing to be read and understood by others. This means that students were simply required to organize their thoughts in sentences composed with some of the rules they had learned and as the example given by a lecturer in the class.

The importance of writing exercises to achieve good writing in accordance with English grammar standards and correct writing techniques was of paramount importance because there were still many students who had not understood these matters. Basic competencies to be achieved include: writing descriptions, writing stories, completing unfinished paragraphs, and compiling paragraphs. The subject matter listed in the syllabus: description of a person, thing, place, and animal based on its characteristics, and a story of experience or event that also includes paying attention to the writing of punctuation and capitalization. From the observation of the interactive teaching found some conditions that need to be followed up, among others:

The implementation of interactive teaching writing was conducted.

It was between a lecturer and students. This was apparent in the classroom writing lessons during observation. At beginning a lecturer spoke more and students listened. In interactive teaching and learning, there were components that must have been done in effective teaching. 
What was meant by effective learning was student-centered learning. Starting from lecturers acting in front of the class, students paid attention to a lecturer acting, and working. A lecturer directing and teaching should have focused on "how to" students use their new knowledge. Learning strategy was more important than the result. Feedback was very important for students, which came from the correct assessment process assessment.

When the observation was done, the lecturer carried out the learning of writing descriptions and experiences, the things described were: how to get information for writing a paragraph, writing paragraph steps, use of topic sentence, and punctuation. Then, the Students and a lecturer discussed. Existing issues such as the content of ideas to be put forward, content organizations, and vocabulary were less widely discussed. The steps of writing lessons had not been systematically. When lecturers started learning, lecturers had not explained the goals / indicators that had to be mastered by students. This needed to be conveyed by the lecturer to the students although verbally in order students would understand the ability to be achieved. Active lecturers transferred knowledge in students. While students had to be able to memorize a number of concepts and facts taught lecturers. Lecturers had not been able to develop learning methods so that students were active in learning activities. The lecturer in teaching did not use a homemade learning plan but only an existing syllabus. The lesson plan used at that time had not been studied before. Teaching preparation was essentially a short-term plan for estimating or projecting what to do. The function of preparation of teaching was to encourage lecturers to be more ready to carry out the learning with careful planning. Therefore, every lecturer would be required to have preparation, either written preparation or unwritten preparation. In addition, the preparation of teaching served to streamline the learning process in accordance with what is planned.

The use of interactive teaching method was still dominant.

The student sounded simultaneously when answering lecturer questions. The courage to ask students had not been seen. The lecturer taught about the structure, it appeared in the explanation of the use of capital letters, punctuation, and paragraph writing. The use of interactive teaching method assessed students' learning outcomes as well as selecting and using learning strategies. While teaching interactive teaching, a lecturer could make small groups of students. The students discussed and shared knowledge about writing skills.

From the description of observation above found in the process of learning to write students in the classroom and questionnaires, teaching interactive writing could be drawn conclusion as follows. So far, learning was still centered on a lecturer. Students listened and practiced. Classroom management was good. Students could work or write well using interactive teaching and some students were still less. However, this method had made change to students' achievement in writing

Seeing from the paragraphs of all the students in writing class, it is necessary to learn the writing habits to optimize the role of students so that active, productive, creating a fun learning atmosphere, achieving meaningful learning outcomes for students and students can produce good writing in the a writing class activities.

\section{Students' Writing and Results}

Based on the results of observations, interviews and questionnaires about the execution of learning writing experience of English literature students, firstly, their interest in writing was still low. It was seen in the activity of students when given the task of writing on the topic free by lecturers. They still did not understand what to write about and they turned right and left to see his friend had started writing and what his friend wrote.

The low writing skills were caused by the low interest and unfamiliarity in writing. Students were not interested to write because they did not know the rules of writing. For students, writing lessons was a tedious lesson. Writing had not made students happy to learn. 
For that, it was necessary to write examples from various media as an illustration for their writing. Writing activities would work if someone was aware of his needs. Awareness writing would lead the students to seek and act to obtain maximum results, so that students would get satisfaction in the fulfillment of their needs. Interest is one's consciousness that an object and a situation are related to itself. So, because there was less of him, there was a need to be met, then with high awareness the student would try to write. Conditions like this over time become a steady habit in students. Without realizing it, the student would be formed interest in writing as well, which would spur the student to improve his writing skills. Students would be active writing if before writing do the following things as the lecturer demonstrated, such as determining topics, collecting information, organizing the framework, developing the topic / organization of content. And after writing review, edited the writing (contents, punctuation, word order, sentence, and paragraph), and revised it. Students would be easier to write when writing about their own experiences. They had the pleasure of writing if doing writing activities without being ordered and filling leisure time / holiday by writing. Students would be easier to write if a lot of reading other people's writing and willing to learn textbooks about writing. That way interactive writing became accustomed to writing and making writing. Moreover reading experience was an important experience.

Before writing a student who accumulated few new past experiences compose the essay before writing a little too new. Most students do not compose the paragraph before writing. It is caused by the lack of knowledge of students on how to prepare the framework of writing. Therefore, teachers need to teach how to frame the paragraph. Before writing students must have things or topics to be written to be developed into their writing. A complete writing requires language. In this case the student must master many vocabulary and grammar that support his idea. This means that the students must use the correct English word and grammar so that the idea can be properly understood by the reader as well. The words should be coupled into good sentences. Subsequently the sentences are organized into eligible paragraphs.

There were still very few students who were used to writing essays in English. They had no interest and motivation to write every day. That was because they did not have the ability to write and did not know what the right writing, let alone revise it. At home some of them were not guided by parents because parents were unable to guide writing in English. For that, lecturers needed to guide students write and revise it and cultivated their writing hobby. And to encourage students to write need communication between students and a lecturer to get any information that they should know to improve their writing skills. Thus, interactive teaching writing is the right method to use in teaching learning process in the classroom.

\section{CONCLUSION}

Based on the formulation of the problems and discussion of research results that had been implemented, it can be concluded that the use of writing activity with interactive teaching method in the process of learning writing could improve the ability to write paragraphs to students of writing class. From the results of this study note that the use of writing activity with on students interactive teaching was a significant impact on improving the ability to write English essay. Besides, the level of their writing interest increased, students were more motivated to write various topics for their paragraphs. In terms of content and organization also had begun in progress and more arranged in order of events with a neat. There were still grammar errors but not too much and the use of vocabulary had started to vary. While the results of student writing after the implementation of interactive teaching, the results of writing that they make was better and get a satisfactory rate. Although there had been progress in writing skills but there were still some students whose grades were not satisfactory and therefore still needed more practice to improve their writing results. 


\section{REFERENCES}

Brown, H.D. (2000). Principle of Language Learning and Teaching. London: Pearson Education Ltd.

Cresswell, J. W. (1994). Research Design: Qualitative and Quantitative Approaches. Thousand Oaks, CA: SAGE.

Flick, Uwe. (2007). Designing Qualitative Research. Thousand Oaks, CA: SAGE.

Harmer, Jeremy. (2011). The Practice of English Language Teaching. Cambridge: PearsonLongman.

Johnson, DW., Jonhson, R, \& Smith, K.A (1998). Active Learning: Cooperative in the College Classroom (2nd Edition). Edina, MN: Interaction Book Company.

Oshima, Alice, et al.(1998). Writing Academic English. (Third Edition). New York: Longman.

Oxford, Rebecca L. (2011). Teaching and Researching Language Learning Strategies. Great Britain: Pearson Education Ltd.

Rivers, Wilga M. (1997). Interactive Language Teaching. USA: Cambridge University Press

Sutopo, (2002). Metodologi Penelitian Kualitatif: Dasar Teori dan Terapannya dalam Penelitian. Surakarta: Sebelas Maret University Press.

Tarigan, H.G. (2008). Menulis Sebagai Suatu Keterampilan Berbahasa. Bandung: Angkasa. 